\title{
Pan/i Detektyw. Tożsamość protagonisty w grach typu Hidden Object Puzzle Adventure
}

Marta Błaszkowska 
Pan/i Detektyw.

Tożsamość protagonisty w grach typu

Hidden Object Puzzle Adventure

Marta Błaszkowska

TEKSTY DRUGIE 2017, NR 3, S. 332-345

DOI: $10.18318 /$ td.2017.3.20

\section{Wprowadzenie}

„Traktujemy robienie gier poważnie. Dlatego zawsze myślimy dwa razy, zanim dodamy do gry jakąś nową funkcję albo zmienimy jakiś jej aspekt"1 - mówił w wystąpieniu wygłoszonym podczas Casual Connect w Belgradzie Vladimir Zivkovic, jeden z twórców pracujących dla studia Eipix Entertainment, produkującego przede wszystkim gry typu Hidden Object Puzzle Adventure (HOPA) ${ }^{2}$. Jednym z wyrazów tego "poważnego traktowania” jest dla Zivkovica położenie nacisku na zagadnienie immersji, której poświęca on swoją prezentację, proponując praktyczne rozwiązania, za pomocą których producenci gier HOPA mogą jego zdaniem wzbudzać w graczach poczucie zanurzenia w świecie przedstawionym. Sama kategoria

1 Por. V. Zivkovic Building immersion in HOPA games, 10.11.2014, https:// www.youtube.com/watch?v=KMNtGgxIUkU [12.12.2016], tłum. moje - M.B.

2 Czyli gier łączących w sobie elementy gry przygodowej typu point \&click, logicznej i polegającej na wyszukiwaniu ukrytych obiektów.
Marta Błaszkowska

- mgr, doktorantka

w Katedrze Antropologii Literatury i Badań Kulturowych UJ. Interesuje się przede wszystkim literaturą i kulturą popularną, szczególnie w ujęciu teorii literatury i kultury, psychoanalizą lacanowską i filozofią dwudziestowieczną. Autorka artykułów w monografiach i czasopismach poświęconych tematyce m.in. polskiej literatury fantastycznej drugiej połowy XX wieku. 
immersji - będąca dziś zresztą przedmiotem licznych i wieloaspektowych rozważań ${ }^{3}$ - staje się w tym przypadku pojęciem porządkującym dywagacje na temat różnych poziomów gry: jej aspektów mechanicznych, graficznych, fabularnych czy dźwiękowych. Istotnymi elementami związanymi zdaniem Zivkovica z immersyjnością gry są np. perspektywa pierwszoosobowa i brak aktora podkładającego głos pod postać protagonisty - jego obecność miałaby bowiem „przypominać ciagle, że to nie jestem ja” ${ }^{\text {" }}$.

Chociaż przywołany powyżej przykład może zdawać się anegdotyczny, jest on w istocie wyrazistym sygnałem tego, w jaki sposób kształtowana jest w grach HOPA relacja między graczem i awatarem. Poziom zanurzenia w świecie gry, o którym mówi Zivkovic, zdaje się bliższy raczej temu, co Emily Brown i Paul Cairns określają jako zaabsorbowanie (engrossment) ${ }^{5}$, a więc emocjonalnemu zaangażowaniu w rozgrywkę, a nie immersji sensu stricto, niemniej już samo odwołanie się do takich kategorii jest symptomatyczne. HOPA należą do gier typu casual, a więc przeznaczonych dla odbiorcy mniej zainteresowanego złożonością rozgrywki i z założenia niejako mniej wymagającego, oczekującego prostej rozgrywki; mimo to również ich okazują się dotyczyć problemy teoretyczne podnoszone w przypadku gier innego typu. Co więcej, być może właśnie w przypadku HOPA zagadnienie relacji gracza i postaci grywalnej jest szczególnie istotne - gry te przecież, ze względu na chociażby stosunkowo krótki czas rozgrywki, nie mają możliwości powolnego zapoznawania grającego $\mathrm{z}$ bohaterem, budowania zaangażowania przez wpływanie na kolejne wybory protagonisty czy stopniowego konstruowania jego osobowości. Tymczasem wciąż dominuje oparte na badaniach z lat 2006-2007 przekonanie, że zdecydowaną większość odbiorców gier casual stanowią kobiety ${ }^{6}$, stereotypowo kojarzone również z emocjonalnym nastawieniem do rozgrywki i potrzebą uczuciowego zaangażowania; w przypadku

3 Por. np. M.L. Ryan Narrative as Virtual Reality. Immersion and Interactivity in Literature and Electronic media, The Johns Hopkins University Press, Baltimore 2001; G. Calleja In-Game from Immersion to Incorporation, The MIT Press, London 2011; A. MacMahan Immersion, engagement and presence: a method for analysing 3- D video games. In The Video Game Theory Reader, Routledge, London 2003. Por. V. Zivkovic Building immersion in HOPA games.

5 E. Brown, P. Cairns A grounded investigation of game immersion, s. 3, https://pdfs.semanticscholar.org/8f11/f8d199fbo8449d47d6edb297899a680od64C.pdf (12.12.2016).

6 Por. Casual Games Market Report 2007, 29.10.2007, http://www.casualconnect.org/newscontent/11-2007/casualgamesmarketreport2007.html (12.12.2016). 
HOPA jest to istotne szczególnie dlatego, że wychodzą one poza prosty, casualowy schemat gier logicznych, nie uwzględniających protagonisty w ogóle. Twórcy stają więc przed koniecznością pogodzenia oczekiwań (projektowanych) odbiorców, ograniczeń narzucanych przez gatunek oraz niezbywalnych elementów przyjmowanych konwencji.

To balansowanie między zapotrzebowaniami a przeszkodami skutkuje wytworzeniem figury protagonisty, która - choć ewoluująca i wytwarzająca stopniowo różne warianty - ma cechy charakterystyczne, przejawiające się w konkretnych growych realizacjach. Przede wszystkim to właśnie oczami głównego bohatera gracz patrzy na świat przedstawiony - i to dosłownie, typowa dla gier HOPA jest bowiem perspektywa pierwszoosobowa. Po drugie, historia i osobowość protagonisty jest najczęściej pełna luk, które, co istotne, nie zostają uzupełnione w toku gry; zazwyczaj grający nie odkrywa wielu personalnych uwarunkowań czy uprzedzeń postaci grywalnej, nie wie zbyt wiele o jej historii, a jeżeli już otrzymuje jakieś informacje na jej temat, mają one zwykle charakter pretekstowy.

Tożsamość protagonisty w grach HOPA może być bardziej lub mniej dookreślona, przy czym oba końce tej skali zawierają w sobie element pewnej ostentacji. Po jednej stronie osi znajdują się sytuacje, kiedy o głównym bohaterze nie wiadomo niemal nic, spełnia on jedynie swoją funkcję, jest właściwie wyzuty z cech indywidualizujących, nie ma nawet twarzy czy imienia, a od innych bohaterów odróżnia się tylko dzięki swoim detektywistycznym umiejętnościom. Druga strona to natomiast przypadki bohaterów, o których teoretycznie wiadomo graczowi wiele - mają oni bowiem twarze, imiona i rodziny; równocześnie jednak silne, niekiedy wręcz przesadne eksponowanie tych elementów nie idzie w parze z prezentacją bardziej skomplikowanych cech osobowości i bynajmniej nie jest związane z większą indywidualizacją postaci grywalnej. Dalsza część tekstu będzie próbą omówienia tej właśnie skali dookreślania tożsamości bohatera gier HOPA ze szczególnym uwzględnieniem wspomnianych przypadków granicznych; za egzemplifikację posłużą dwie wydawane od dłuższego czasu, wieloczęściowe i uznane w środowisku graczy serie - Mystery Case Files i Grim Tales.

\section{Uparte ukrywanie}

Czternastoczęściowa obecnie seria Mystery Case Files, której pierwsza odsłona, zatytułowana Huntsville, ukazała się pod koniec 2005 roku, właściwie od początku jest jednym z najszerzej rozpoznawalnych cyklów gier typu 
HOPA'; obejmuje nie tylko gry przeznaczone na komputery osobiste, ale również tytuły na inne platformy oraz cztery powieści (określane jako A Blackpool Mystery Series) ${ }^{8}$. Zmiany zachodzące w obrębie tej serii w czytelny sposób odzwierciedlają trendy rozwojowe całego gatunku. Pierwsze części Mystery Case Files to gry polegające wyłącznie na wyszukiwaniu ukrytych obiektów w obrębie obrazka i układaniu prostych puzzli; ich fabuła jest zupełnie marginalna, pojawia się jedynie jako tło między kolejnymi etapami rozgrywki. Kolejne odsłony wprowadzają inne typy zagadek oraz komplikacje w łamigłówkach hidden object scenes (HOS), a począwszy od czwartej, Return to Ravenhearst - również elementy klasycznej gry przygodowej, dzięki czemu gry te zaczęły przypominać HOPA w dzisiejszym rozumieniu. Także w obrębie tej właśnie serii pojawiły się pierwsze innowacje formalne, takie jak wprowadzenie interaktywnej mapy (Shadow Lake) czy użycie przerywników filmowych z udziałem żywych aktorów (Dire Grove).

Cykl Mystery Case Files zasadniczo nie jest spojony jedną linią fabularną, da się jednak w nim wyróżnić pewne powracające wątki, a bohaterowie (zwłaszcza antagoniści) pojawiają się czasami w kolejnych częściach9. Tym jednak, co najbardziej zwraca uwagę, jest wspólna dla wszystkich odsłon kreacja protagonisty. Od początku postacią grywalną jest osoba określana jako „Master Detective", pracująca w organizacji rozwiązującej zagadki kryminalne,

7 Mystery Case Files: Ravenhearst było w USA podczas tzw. czarnego piątku w 2007 roku trzecią najlepiej sprzedającą się grą, a według szacunków producenta wersje trial gier z serii tylko do roku 2007 zostały pobrane z oficjalnej strony około 100 milionów razy. Por. S. Hillis "Hidden object" series hit for holidays, 20.12.2007, http://www.reuters.com/article/us-videogamesmysterycasefiles-idUSN1851179620071220?sp=true\&view=sphere (10.12.2016).

8 Ich autorem jest Mel Odom (piszący w tym przypadku pod pseudonimem, jako Jordan Gray), skądinąd znany również jako autor powieściowych adaptacji komiksów o nastoletniej czarownicy Sabrinie, a także książek z uniwersum Forgotten Realms oraz z tzw. Buffyverse.

9 Najczęściejpowracającym wątkiem fabularnym jest niewątpliwie historia osnuta wokółposiadłości Ravenhearst - nawiązują do niej części Ravenhearst, Madame Fate, Return to Ravenhearst, Escape From Ravenhearst, Fate's Carnival, Key to Ravenhearst oraz Ravenhearst: Unlocked. Jednak nawet w obrębie tej grupy fabuła komplikuje się i rozgałęzia, a elementem łączącym są postaci głównych wrogów protagonisty: Charlesa i Alistaira Dalimarów. Co interesujące, spójnik stanowią także pewne rozwiązania formalne: mimo zmiany wydawcy serii (ze studia Big Fish Games na Elephant Games, a następnie Eipix Entertainment) nowi twórcy nie zdecydowali się na użycie w odsłonach serii związanych z wątkiem Ravenhearst na wykorzystanie przerywników filmowych z udziałem aktorów, ponieważ nie było ich w pierwszych częściach tego cyklu tematycznego. 
początkowo działająca na zlecenie lokalnych władz, a później otrzymująca zadania bezpośrednio od brytyjskiej królowej.

Te kilka informacji to właściwie jedyne dane, jakie grający otrzymuje na temat głównego bohatera serii. Nawet jego płeć nie jest określona - nic nie sygnalizuje jej ani bezpośrednio (inni bohaterowie zawsze nazywają postać grywalną po prostu detektywem), ani też pośrednio: protagonista nie mówi głosem aktora (jego komentarze wyświetlają się w postaci tekstu na górze ekranu), nie pokazuje również graczowi twarzy ani ciała, $\mathrm{z}$ wyjątkiem krótkich momentów, gdy da się zobaczyć na ekranie dłonie, przy czym zazwyczaj osłonięte rękawiczkami uniemożliwiającymi rozpoznanie, czy są one kobiece, czy męskie ${ }^{10}$. Co więcej: główny bohater serii wydaje się - jakby na podobieństwo bohaterów westernów i innych gatunków popularnych - przybywać znikąd i po zakończeniu misji również rozpływać się w niebycie, by czekać na kolejne wezwanie. Jedynymi dostępnymi graczowi elementami jego przeszłości są te, które zostały przedstawione w kolejnych częściach serii - protagonista dźwiga bagaż doświadczeń związanych zwłaszcza z dramatycznymi wydarzeniami, do których doszło w Ravenhearst, i nieustannie ścigają go wrogowie tam spotkani. Nie pojawiają się natomiast w Mystery Case Files żadne nawiązania do historii postaci grywalnej, jej rodziny czy zdarzeń z dalszej przeszłości. Nie ma tu nawet, chętnie wykorzystywanego przez twórców gier HOPA i wzorowanego na konstrukcji opowiadania detektywistycznego, motywu rozpoczęcia sprawy w biurze protagonisty: w serii rozgrywka każdorazowo rozpoczyna się od razu w miejscu, które będzie badane podczas śledztwa - często przed bramą domu.

Szczególnie interesująca w tym kontekście okazuje się kwestia imienia protagonisty - a raczej jego braku. W każdej z kolejnych części serii natychmiast po uruchomieniu gry użytkownik jest poproszony o wpisanie imienia; rzecz jasna, nie jest to sytuacja niespotykana, podobny wymóg powszechnie dotyczy HOPA, a także wielu gier innego typu. W pierwszych częściach $M y$ stery Case Files można to rozwiązanie bez trudu wytłumaczyć: po zakończeniu rozgrywki, jeżeli gracz rozwiązał zagadki w odpowiednio krótkim czasie, jego imię trafiało do rankingu. Tym, co zwraca uwagę, jest jednak fakt, że gra

10 Zabieg ten pierwotnie jest związany prawdopodobnie z potrzebą ukrycia koloru skóry bohatera i uniknięcia w ten sposób jakichkolwiek odwołań do kwestii rasowych, co ma szczególne znaczenie w przypadku produktów kierowanych również na rynek np. amerykański. Jednakże z łatwością da się tu nadbudować interpretację właśnie w kluczu genderowym. 
wyraźnie prosi nie o to, by nazwać postać (lub nawet konto), ale by podać „swoje imię" („Please enter your name”) i to ono zostaje w sposób bezpośredni przeniesione na głównego bohatera. Dowodem tego może być chociażby scena, w której „Master Detective” znajduje przygotowany dla siebie nagrobek: jest na nim wyryte właśnie to imię, które gracz podał na początku. Protagonista jest więc de facto pozbawiony własnego imienia - z założenia nosi tylko imię gracza, a tytuł, którym inni zwracają się do niego, przypomina przydomki nadawane przez towarzyszy Claude'a Lévi-Straussa obserwowanym członkom plemienia Nambikwara: stanowi zasłonę, za którą miałoby się skrywać prawdziwe imię własne, takie, które nazywając, stwierdza istnienie. Tyle że to rzekomo rzeczywiste imię istnieje tylko w takiej formie, w jakiej zostało podane przez gracza - i nie ma nawet w tym przypadku mowy o derridiańsko rozumianej przemocy nazywania, opresji, która wiąże się z odgórnie podjętą próbą okiełznania nieokiełznanego Innego i wpisania go w system ${ }^{11}$. Gest twórców gry (pragnących wywołać u grającego wrażenie zanurzenia $\mathrm{w}$ świecie przedstawionym) prowadzi bowiem rzeczywiście w pewien sposób do utożsamienia się z protagonistą - inność tego ostatniego zostaje jednoznacznie przekreślona, kiedy gracz nie tylko po prostu nazywa go ja ko ś, ale nazywa go s a my m sobą - jednak jest przy tym gestem zdradliwym i łatwo mogącym zadziałać jak miecz obosieczny. Grający podaje swoje imię, a więc poniekąd, jak określiłby to Jacques Derrida, składa sygnaturę; imię to ma go bezdyskusyjnie wyróżniać, a przy tym ma być dowodem na to, że to właśnie jego rozgrywka, za którą bierze odpowiedzialność, pod którą podpisuje się jako podmiot, zgadzający się odtąd na reguły gry, w którą się włącza. Ale przecież ta odpowiedzialność jest tylko pozorna, ponieważ jak już podkreślono, wpływ gracza na świat gry HOPA jest tak niewielki, że nie ma tu właściwie mowy o żadnej indywidualizacji rozgrywki; nie ma też rzeczywistego wpływu na postać protagonisty, który na wydarzenia reaguje tylko krótkotrwałymi, sygnalizowanymi pobieżnie emocjami, nie zmieniając się pod wpływem nawet najdziwniejszych sytuacji. Tym samym gest podpisania się i podzielenia z głównym bohaterem własnym imieniem (a więc niejako włączenia postaci w obręb własnej podmiotowości) równocześnie wzmacnia immersję i od razu bierze ją w nawias. Nadawanie przez gracza imienia sobie - i przez to pośrednio awatarowi, będącemu jego przedłużeniem w grze wiąże się oczywiście $\mathrm{z}$ „utratą tego, co własne, absolutnej bliskości, obecności

11 Por. M.P. Markowski „Cóż jest w imieniu?”, w: tegoż Efekt inskrypcji. Jacques Derrida i literatura, Homini, Bydgoszcz 2003, s. 273-274. 
dla siebie [...] która nigdy nie była dana, lecz wymarzona"12. To wysoka cena, którą grający jest gotów zapłacić, ale w tym przypadku otrzymuje w zamian nie interakcyjność medium wchłaniającego do swojego świata, a tylko obietnicę immersji, którą zastępuje w istocie obudowane na prostych emocjach (zaskoczeniu, strachu, krótkotrwałym wzruszeniu) zaabsorbowanie ${ }^{13}$.

\section{Ostentacyjne obnażanie}

Seria Grim Tales, produkowana przez Elephant Games, zaczęła ukazywać się dopiero w roku 2011, ale od tamtej pory doczekała się już jedenastu odsłon. W wielu aspektach gry z tego cyklu stanowią modelowe przykłady HOPA: od początku mają one strukturę typową dla współczesnych produkcji tego typu (choć oczywiście również w obrębie tej serii zachodzą drobne modyfikacje, odzwierciedlające zmiany trendów dotyczących całego gatunku) i operują fabułami detektywistycznymi nasyconymi licznymi elementami fantastycznymi. Tłem wszystkich niesamowitych zdarzeń jest historia rodziny, której członków, nieustannie wikłających się w nowe kłopoty, ratuje każdorazowo pełniąca funkcję detektywa główna bohaterka. Już od pierwszej części gry (The Bride) jest ona określoną osobą należącą do konkretnego rodu, chociaż początkowo pozbawioną jeszcze wielu właściwości: na początku wiadomo o niej tylko, że jest kobietą, imię zyskuje mniej więcej w połowie serii, a później jest już określana dokładnie jako "miss Anna Gray” albo - częściej - „Aunt Gray"14. Można też czasem zobaczyć w kadrze jej tułów czy nogi a więc już nie tylko dłonie - natomiast w jednej z późnych części pojawia się nawet jej portret. Gracz ma też możliwość obejrzenia jej biura, w którym np. rozpoczyna się akcja jedenastej części gry, Crimson Hollow.

Mogłoby się wydawać, że tak wyraźnie zarysowana bohaterka stanowi przeciwieństwo niedookreślonego detektywa z Mystery Case Files i że zbliża serię Grim Tales do typowych gier „poważnych”, które mogą budować zaangażowanie gracza m.in. przez podsycanie zainteresowania historią i rozwojem postaci grywalnej. Dokładna analiza postaci protagonistki cyklu budzi jednak co do tego wątpliwości. Od połowy serii widoczne są próby uprawdopodobniania i uspójniania historii rodu, z którego wywodzi się bohaterka,

12 J. Derrida O gramatologii, przeł. B. Banasiak, Wydawnictwo Officyna, Łódź 2011, s. 158-159.

E. Brown, P. Cairns A grounded investigation of game immersion.

14 Por. np. Grim Tales: The Final Suspect Collector's Edition, http://www.bigfishgames.com/games/11154/grim-tales-the-final-suspect-ce/?pc (12.12.2016). 
a także tworzenia swoistej bazy danych na temat świata przedstawionego: pojawiają się opisy poszczególnych postaci, ich figurki, portrety rodzinne, a w przedostatniej obecnie części, The Heir - nawet drzewo genealogiczne. Jednak jako że w pierwszych częściach cyklu kolejne postaci należące do rodziny pojawiają się tłumnie, ten gest porządkowania - wykonywany przecież wobec już zaistniałego świata przedstawionego - niesie ze sobą konieczność redukcji i równocześnie uzupełnienia miejsc niedopowiedzianych; $w$ ten sposób niektórzy członkowie rodziny zostają przemilczani, a innym np. wtórnie dodawani są małżonkowie i dzieci. To z kolei prowadzi do luk fabularnych śledzenie rodzinnych wątków pojawiających się w Grim Tales ujawnia liczne takie nieścisłości, z których najistotniejszą wydaje się kwestia tak podstawowa, jak nazwisko rodowe. W The Bride gracz z sekwencji filmowej otwierającej grę dowiaduje się, że protagonistka i jej siostra, Luisa, ostatni raz spotkały się, będąc jeszcze dziećmi i że miały się zobaczyć z okazji ślubu Luisy właśnie, ale do spotkania nie doszło, ponieważ panna młoda w dniu wesela zmarła w tajemniczych okolicznościach, pogrążając rodzinę w żałobie i zmuszając siostrę do rozwiązania zagadki tej nieoczekiwanej śmierci. Kiedy bohaterka przybywa do rodzinnego zamku, spotyka tam nieznajomego, który oferuje jej szansę powrotu w czasie i uratowania Luisy (umiejętność przenoszenia się do własnych i cudzych wspomnień będzie zresztą dana Annie już na stałe i stanie się motywem przewodnim kolejnych części gry). Już w pierwszej scenie z przeszłości pojawia się narzeczony Luisy, John, określany konsekwentnie jako „John Gray"; siostra protagonistki jako jego żona, owszem, dzieli z nim to nazwisko, ale nie ma już żadnej przyczyny, dla której miałaby je nosić główna bohaterka, a także, jak się potem okazuje, cały ród, funkcjonujący od pewnego momentu - prawdopodobnie na skutek niedopatrzenia twórców - jako „rodzina Gray”.

Fasadowy charakter tożsamości postaci grywalnej w Grim Tales wynika zresztą w dużej mierze właśnie z tego, że rzeczywistym głównym bohaterem serii bardziej niż Anna Gray zdaje się być raczej cała rodzina Grayów. Wszystkie aktywności Anny podporządkowane są ratowaniu i wspieraniu krewnych, przybywa ona na każde wezwanie najpierw siostry, a następnie również innych członków rodziny, a w kolejnych odsłonach serii coraz mocniej podkreślana jest więź, jaka łączy Grayów. Odkrywanie tajemnic rodowych - których, jak się okazuje, jest bardzo wiele - pochłania protagonistkę całkowicie; wprawdzie gracz jest czasem informowany o tym, że Anna prowadzi biuro detektywistyczne i, w domyśle, rozwiązuje również inne sprawy, ale zawsze pozostają one w sferze niedopowiedzenia, seria natomiast koncentruje się 
na tragediach przydarzających się mniej lub bardziej ze sobą spokrewnionym członkom wielopokoleniowego rodu Gray. Sygnałami tego całkowitego podporządkowania sprawom Grayów są z jednej strony wspomniane już częstsze określanie Anny w kontekście jej pozycji w rodzinie („Aunt Gray”) niż za pomocą jej własnego imienia, z drugiej natomiast sposób, w jaki został domknięty wątek tej postaci w Crimson Hollow, aktualnie ostatniej części cyklu. Omawiając to domknięcie, należy najpierw podkreślić, że w jednej z poprzednich odsłon cyklu niemal wszyscy członkowie rodziny tajemniczo znikają, bohaterka zaś stara się ich odnaleźć. Crimson Hollow rozpoczyna się od sekwencji filmowej, w której Anna spogląda na drzewo genealogiczne, mówiąc przy tym o nieudanych poszukiwaniach, a także o braku innych klientów ${ }^{15}$. To pierwszy w serii moment, w którym pojawia się ślad emocjonalnej wyrwy - bohaterka wspomina „constant family drama”, wprost wyrażając tęsknotę, wynikającą nie tylko z nudy, ale też z różnicy między obecnym trybem życia a modelem zachowania, do którego przywykła. W momencie zniknięcia rodziny przestaje istnieć również punkt odniesienia - niemożliwe jest już dłuższe samodefiniowanie się bohaterki przez jej familijne uwikłania. Proces przepracowania tej sytuacji przebiega zaskakująco: Anna w zakończeniu gry decyduje się na małżeństwo, co można zinterpretować przynajmniej dwojako - z jednej strony jako wyzwolenie się do własnego życia po latach podporządkowywania się cudzym problemom, z drugiej natomiast jako wejście w kolejną relację określania się w stosunku do Innego. Faktyczną kliszowość tego rozwiązania fabularnego podkreśla dodatkowo fakt, że bohaterka jakiś czas wcześniej zostaje w cudowny sposób odmłodzona - rozpoczyna więc defacto zupełnie nowe życie w miejsce tego, które oddała rodzinie, natomiast funkcję detektywa przejmuje po niej daleka krewna, pozbawiona podobnego bagażu doświadczeń, ale dysponująca tymi samymi mocami.

Sugerowana w Grim Tales wyrazista tożsamość bohaterki okazuje się więc w istocie maską, za którą tkwi postać niemal bez właściwości, zupełnie przypominająca w tej kwestii tajemniczego detektywa z Mystery Case Files. Sterowanie jej poczynaniami przez gracza przebiega według ustalonego z góry, liniowego schematu, bez możliwości wyboru między jakimikolwiek opcjami, a jedyną konsekwencją podejmowanych działań jest popchnięcie do przodu fabuły gry, które z całą pewnością nie będzie wiązało się z jakąkolwiek

15 Dokładnie: „I've had no luck finding any members of the Gray family. I haven't had any clients either. I never thought I'd miss my constant family drama, but here I am..." - Elephant Games Grim Tales 11. Crimson Hollow [PC], 2016, Elephant Games. 
rzeczywistą zmianą w psychicznej konstrukcji postaci. Cała wiedza, jaką gracz dysponuje na temat postaci Anny, jest związana z jej życiem rodzinnym, a co dodatkowo istotne: brak tu właściwie miejsca na dopowiedzenie jakichkolwiek indywidualizujących cech; niemożność naruszenia liniowego schematu rozgrywki, jedno możliwe zakończenie gry, podporządkowanie fabuły postaciom innym niż protagonista - to wszystko składa się na konstrukcję bohatera, którego gracz nie jest w stanie w żaden sposób ukształtować. Co należy podkreślić, zanik tożsamości postaci gracza ${ }^{16}$ nie jest tutaj bynajmniej równoznaczny z większą liczbą cech składających się na tożsamość bohatera gry, a więc własności postaci wybranych odgórnie przez twórców ${ }^{17}$ : jak już wspomniano, cechy rzekomo indywidualne bohaterki Grim Tales są jedynie pretekstowe, a nawet pobieżna próba interpretacji ujawnia, że nie wiadomo nic o zapatrywaniach Anny na świat, jej własnych wyborach czy decyzjach życiowych.

Najbardziej wyróżniającą cechą protagonistki Grim Tales jest więc jej niewyróżnianie się prawie niczym - i ciągłe funkcjonowanie w zależności od Innego. To ostatnie widoczne jest zresztą także w samym przebiegu rozgrywki: wszystkie ważne momenty fabularne są efektem współpracy bohaterki z kimś, kto ją prowadzi i kto udziela dokładnych wskazówek. Nawet szczególna moc Anny - umiejętność przemieszczania się w czasie - ujawnia się tylko dzięki poradom udzielanym jej głównie przez duchy przodków albo inne postaci obdarzone wyjątkową wiedzą ${ }^{18} \mathrm{i}$ działa jedynie wtedy, kiedy ktoś z zewnątrz powie protagonistce, że można tej mocy użyć. Ta sytuacja bezustannej zależności ujawnia podobną jak w przypadku Mystery Case Files sprzeczność: z jednej strony zdaje się umożliwiać graczowi postrzeganie awatara jako przedłużenia własnej osoby (brak cech indywidualizujących i absolutna uległość pozornie negują przecież „obcość obcego", która stanowiłaby zagrożenie dla heteronomii poznającego podmiotu ${ }^{19}$ ), $\mathrm{z}$ drugiej natomiast odzwierciedla sytuację samego grającego, który zmuszony jest bezdyskusyjnie poddać się

Por. M. Petrowicz Mechaniki tworzenia postaci, „Homo Ludens” 2015 nr 2 (8), s. 138.

\section{Por. tamże.}

Na czele z głównym antagonistą serii, Richardem Grayem, który wprawdzie formalnie zmienia się z przeciwnika w pomocnika dopiero w ostatniej części gry, natomiast już wcześniej to on uczy protagonistkę posługiwania się nadprzyrodzonymi umiejętnościami.

Por. E. Lévinas Całość i nieskończoność. Esej o zewnętrzności, przeł. M. Kowalska, PWN, Warszawa 1998, s. 31-32. 
narzuconemu modelowi rozgrywki - uwidacznia więc boleśnie, że „to nie ja myślę i czuję. To mnie się myśli i czuje”20.

\section{Strategie i narzędzia}

Pierwszoosobowa perspektywa stosowana w grach typu HOPA, połączona często (jak w przypadku Mystery Case Files) z konsekwentnym nieukazywaniem twarzy i ciała bohatera w żadnej sytuacji, skutecznie odcina możliwość zaprezentowania postaci grywalnej za pomocą najbardziej oczywistego elementu, czyli jej wyglądu. Otwiera to, rzecz jasna, szansę na niedopowiedzenie i, jeżeli przyjąć przywoływaną na początku tezę Zivkovica, sprzyja uzyskiwaniu efektu immersji, na którym zależy twórcom gier HOPA. Mechanizmów ukrywania protagonisty jest zresztą więcej; niektóre z nich (zastosowanie rękawiczek, rezygnacja z podkładania głosu aktorskiego) zostały już wspomniane przy omówieniu serii Mystery Case Files, do innych należy chociażby manipulowanie kwestią możliwości wykonania przez bohatera zadania siłowego. Większość gier nie uzależnia szansy np. na przeniesienie czegoś od fizycznej siły protagonisty - jeżeli w toku rozgrywki pojawia się motywowany płcią postaci grywalnej problem z pokonaniem tego rodzaju wyzwania, należy to uznać za silny sygnał dążenia do indywidualizacji bohatera. Jednakże również ten aspekt ma drugie dno: zabiegi takie typowe są raczej dla produkcji starszych, właściwych dla etapu, kiedy gry HOPA mocniej niż współcześnie dzieliły się na dwa rodzaje: te kierowane wprost do kobiet (lub dzieci), gdzie w roli protagonisty występowała zwykle księżniczka lub innego rodzaju postać utożsamiana z czystością serca i prawością umysłu, a nie z przymiotami fizycznymi czy choćby odwagą, oraz takie, które koncentrowały się na szerszym gronie odbiorców, wykorzystujące klasyczne wątki przygodowe i ustawiające w funkcji głównego bohatera zwykle sprytnego i doświadczonego detektywa.

Głównym sposobem bezpośredniego komunikowania się awatara z graczem są wypowiedzi protagonisty wyświetlające się co pewien czas na ekranie, za pomocą których komentuje on bieżące wydarzenia. Omówienie szczegółowych aspektów tego zagadnienia wymagałoby oczywiście skrupulatnej analizy, która wykracza poza temat niniejszego artykułu - warto jednak w tym miejscu wskazać, że chociaż możliwości płynące z zastosowania tego

20 Por. M.P. Markowski Polityka wrażliwości. Wprowadzenie do humanistyki, Universitas, Kraków 2013, S. 295. 
zabiegu wydają się szczególnie duże (tekst mógłby przecież funkcjonować tu jako przekaźnik tych „idiomatycznych znamion” jednostki, o których pisze Derrida i które za nim analizuje Michał Paweł Markowski²1), to w praktyce są one rzadko wyczerpywane. $\mathrm{W}$ istocie wypowiedzi protagonisty przybieraja zwykle kształt przewidywalnych, czasem ironicznych lub humorystycznych komentarzy, które nie mówią właściwie nic o wygłaszającej je postaci.

Wydaje się więc, że poziom niedopowiedzenia protagonistów, w grach typu HOPA zresztą szczególnie duży, co pokazują obie omawiane serie, tworzy idealną przestrzeń do narzucania im cech gracza. Tworzące się w ten sposób miejsca niedookreślenia, wymagające konkretyzacji, dopominające się tego, by grający w procesie recepcji odpowiedział na wezwanie tekstu, reagując uzupełnieniem jego braków. Jednakże, jak pokazały analizy Mystery Case Files i Grim Tales, w przypadku tych cyklów gier hipotetycznie immersyjny efekt, który może wynikać z naturalnej potrzeby konkretyzacji, zostaje zakłócony m.in. przez to, że z perspektywy gry byłaby to konkretyzacja dotycząca przede wszystkim miejsc niedopowiedzenia rozumianych ,jako opuszczenie spraw ubocznych, a przeważnie jako uzupełnienia"22 . Jeżeli nie zostaną one nadbudowane treścią wniesioną przez gracza, nic się nie stanie - i właściwie nie dzieje się nic, kiedy gracz rzeczywiście tę treść nadbuduje, bowiem struktura gry jest $w$ istocie strukturą domkniętą, liniową $i$ to ona rządzi grającym, nie pozwalając mu na ingerencję we własną integralność.

\section{Punkty styczne}

W 2011 roku Francesco Alinovi zaproponował podział awatarów na cztery grupy w zależności od tego, w jakim stopniu - jak głęboko - została zaprojektowana ich osobowość. Na jednym końcu skali znajdują się bohaterowie, których określa jako a-dimensional, „nie-wymiarowych”, a więc takich, w przypadku których stopień dookreślenia jest zerowy, co w domyśle wiąże się z możliwością czy nawet koniecznością projekcji cech gracza na postać $^{23}$. Drugi biegun to z kolei awatary „trójwymiarowe” (three-dimensional)

21 M.P. Markowski „Cóż jest w imieniu?”, s. 282-283.

W. Iser Apelatywna struktura tekstów: nieokreśloność jako warunek oddziaływania prozy literackiej, przeł. M. Łukasiewicz, „Pamiętnik Literacki” 1980 z. 1, s. 267. nal of Games Criticism" 2014 No. 1, http://gamescriticism.org/articles/papale-1-2/ (10.12.2016). 
- „te niezapomniane, o bogatej, złożonej osobowości”24. Luca Papale, rozbudowując tę koncepcję, wiąże poziom skomplikowania charakteru bohatera $\mathrm{z}$ rodzajem i stopniem emocjonalnego zaangażowania gracza, mogącego reagować na pięć sposobów: przez odcięcie się, projektowanie swoich cech na awatara, identyfikowanie się z cechami postaci, sympatię bądź empatię. W świetle tej teorii oba omawiane wyżej cykle gier HOPA przedstawiają się dość interesująco.

Po pierwsze, zarówno Mystery Case Files, jak i Grim Tales w sposób ewidentny wykorzystują protagonistów, którzy według typologii Alinoviego przynależą do grupy raczej tych „nie-wymiarowych”; nawet jeżeli przyjąć, że Annę Gray można określić jako bohaterkę „) jednowymiarową” (a więc o stopień bardziej skomplikowaną), należy przypomnieć o fasadowości jej osobowości i o tym, że w jej przypadku jedyną wyróżniającą cechą jest szczególny kształt jej relacji z innymi - podporządkowanie sprawom rodzinnym. W tym miejscu należy postawić pytanie o to, czy ten niski poziom dookreślenia postaci rzeczywiście w przypadku omawianych cyklów idzie w parze z postulowanym przez Alinoviego i Papalego projektowaniem cech gracza na postać. Jest to, oczywiście, pytanie bez jednoznacznej odpowiedzi, ponieważ z pewnością ostatecznie kwestia ta zależy od konkretnego gracza i jego metody obcowania z rozgrywką. Jednakże omówione już czynniki wskazują, że w istocie gry typu HOPA nie pozostawiają graczowi przestrzeni do rzeczywistej konkretyzacji, nie wymuszają jej ani też w żaden sposób do niej nie zachęcają.

W tym miejscu pojawia się więc oczywista aporia - mówiąc za Josephem Hillisem Millerem, tekst inscenizuje na sobie samym akt dekonstrukcji ${ }^{25}$; zabieg, który miałby sprzyjać wywołaniu u gracza poczucia zanurzenia w świecie przedstawionym, kusi go do tego, a równocześnie tym samym gestem zniechęca, zamykając się na indywidualizację. Trudno zatem w tej sytuacji orzec, jakie emocje i jaki typ zaangażowania może wywoływać w grającym taki przypadek. Z pewnością trudno o utożsamienie - ale również o przeniesienie cech własnych na postać. Zgodnie z typologią Alinoviego i Papalego dostępne są więc jeszcze trzy drogi - empatia, sympatia i odcięcie się. Dwie pierwsze silnie związane są z pewnością z wspominanym przez Brown i Cairnsa zaabsorbowaniem, wynikającym z czasowego zawieszenia przez gracza niewiary w realizm świata przedstawionego i pochłonięcia przez emocje, które bądź współdzieli z protagonistą, bądź też stara się zrozumieć i na

24 Tamże, tłum. moje - M.B.

25 Por. J. Hillis Miller Theory now and then, Harvester-Wheatsheaf, New York 1991, s. 108. 
nie zareagować. Pozostaje pytanie, czy jest to optymalny rezultat, jaki mogą osiągnąć gry typu HOPA, jeżeli w ogóle mają zajmować się kwestią zaangażowania emocjonalnego swoich graczy w rozgrywkę. A w opozycji - trzecia z dróg, odcięcie się, czyli krytyczna postawa ironisty.

\section{Abstract}

\section{Marta Błaszkowska}

JAGIELLONIAN UNIVERSITY (CRACOW)

Mr/Ms Detective: The Protagonist's Identity in Games Such as Hidden Object Puzzle Adventure

Błaszkowska examines the way in which games such as Hidden Object Puzzle Adventure (HOPA) determine the protagonist's identity. These games engage the player mostly through a focus on logistical problems, and rarely delve into psychological or sociological issues. This foregrounds the role of the game's protagonist, through whose eyes the player sees the gameworld. Błaszkowska discusses two series - Mystery Case Files and Grim Tales - and contextualizes them with similar productions. This allows her to reveal how the protagonist's usually vague identity is represented as well as the consequences of such representations.

\section{Keywords}

HOPA, hidden object, identity, name, deconstruction 